\title{
The influence of wooden interior materials on indoor environment: a review
}

\author{
Tuomas Alapieti $^{1} \cdot$ Raimo Mikkola $^{1} \cdot$ Pertti Pasanen ${ }^{2} \cdot$ Heidi Salonen $^{1}$
}

Received: 30 September 2019 / Published online: 5 May 2020

(c) The Author(s) 2020

\begin{abstract}
Environmental issues and health-benefitting design strategies have raised interest in natural and renewable building materials, resulting in an increased focus on the use of wood in built environment. The influence of wooden materials on measured and perceived indoor environment quality (IEQ) has gained attention during the past few decades, with a growing number of studies having explored the issue. This review was conducted to examine and summarise the body of research on the influence of wooden interior materials on IEQ, with an emphasis on the following themes: emissions of chemical compounds, moisture buffering of indoor air, antibacterial effects, acoustics, and psychological and physiological effects. This review found that wooden interior materials exert mainly positive or neutral effects on IEQ, such as moderating humidity fluctuations of indoor air, inducing positive feelings in occupants, and inhibiting certain bacteria. Negative effects on IEQ are limited to volatile organic compounds emitted from wood. The odour thresholds of some aldehydes and terpenes are low enough to affect the perceived IEQ. Additionally, concentrations of formaldehyde and acrolein may under certain conditions cause adverse health effects. Further studies are needed to better understand these phenomena and take advantage of the beneficial effects while hindering the unpleasant ones.
\end{abstract}

Keywords Wood $\cdot$ Indoor environment $\cdot$ Moisture buffering $\cdot$ Antibacterial effects $\cdot$ Acoustics $\cdot$ Psychological effects

\section{Introduction}

Wood has several characteristics that makes it a versatile building material. It is light and easy to work with, bears compression and traction forces, and has good thermal insulation properties. Thus, it can be applied as a structural, insulating, and surface material. As a structural material it has been used traditionally in single-family buildings, with $8-10 \%$ of single-family buildings in the European Union (EU) having a wooden frame and regional variations ranging from above $80 \%$ in Nordic countries to near zero in many southern European countries (Hurmekoski 2017). Due to the emergence of engineered wood products and new building systems in recent decades, wood architecture has grown to a level where it now competes with concrete and steel in

Tuomas Alapieti

tuomas.alapieti@aalto.fi

1 Department of Civil Engineering, Aalto University, 02150 Espoo, Finland

2 Department of Environmental Sciences, University of Eastern Finland, 70211 Kuopio, Finland large-scale construction. Additionally, for a long time it has been used as an interior material in all kinds of buildings as a wall, ceiling, floor, and furniture material.

Simultaneously, the built environment's effect on human health and well-being has become an increasingly prominent societal topic, and poor indoor environment quality (IEQ) may affect health, comfort, productivity, cognitive function, and work performance negatively (Wyon 2004; Salonen 2009; Al Horr et al. 2016). As people in Western countries spend most of their time indoors, creating indoor environments that benefit physical and mental health and well-being is a relevant goal. Green spaces and natural environments have indicated to facilitate relaxation, reduce stress, and improve human mood states, as well as creativity (Tsunetsugu et al. 2010; Tyrväinen et al. 2014). However, opportunities for direct contact with nature are diminishing as a consequence of modern urban life; therefore integrating natural elements into the built environment could be one way to increase these encounters (Joye 2007).

Nature's restorative effects are assumed to result from humans' innate affinity for and connection with natural systems and processes, also referred to as the biophilia hypothesis 
(Kellert and Wilson 1993). Biophilic design, a design movement concerning the built environment, utilises the hypothesis by connecting humans to nature through design with natural elements, such as views to nature, natural light, plants, and natural materials, which have been shown to benefit human health and well-being (Kellert et al. 2008). Other design strategies, such as restorative environmental design, are combining aspects from biophilic design with sustainability to create environments and buildings that emphasise occupants' well-being with small or moderate environmental impacts (Nyrud and Bringslimark 2010; Burnard and Kutnar 2015).

In this context, wood is particularly interesting, as it is a natural, renewable, low-carbon, reusable and recyclable building material that already is used widely in the construction industry. The global construction and building sector is responsible for $42 \%$ of total energy consumption and 35\% of total greenhouse gas emissions (Hurmekoski 2017). By increasing the use of wood from responsibly managed forests as a building material, it is possible to reduce these construction-related disadvantages. Wood is known to sequester carbon dioxide during product's service time, and with long lasting products the advantages are clear when compared to traditional building materials like concrete, steel or bricks (Salazar and Meil 2009; Asdrubali et al. 2017). Furthermore, wooden building products typically require less energy to manufacture, and after a building's life cycle ends, the remaining wood waste serves various purposes (Salazar and Meil 2009).

Over the past couple of decades, more and more studies have appeared on the possible health benefits of wood, with the assumption that it might elicit effects in the built environment that resemble other natural elements. In addition, it has been reported that using wood as an interior material affects the indoor environment of a building in several ways: Wood emits chemical compounds, buffers the moisture content of indoor air, and influences the acoustical as well as bacterial environment (Risholm-Sundman et al. 1998; Li et al. 2012; Asdrubali et al. 2017; Vainio-Kaila 2017). However, a comprehensive summary of the effects of wooden building materials on measured and perceived IEQ is needed. Therefore, the objective of this study was to review previous research done within these fields and build a summary of how wooden building materials in indoor settings affect IEQ.

\section{Methods}

The literature for this review was produced from Google Scholar and PubMed online databases using search terms and different combinations related to wood and the indoor environment (e.g., 'wood', 'wood material', 'VOC emissions', 'indoor environment', 'moisture buffering', 'acoustical performance' and 'psychological effects'), generally one topic at a time. Following this, the search was extended to lists of references in broadly relevant articles (based on their titles and/or abstracts). We also searched for work by authors (Burnard, M.; Fell, D.; Gminski, R.; Hameury, S.; Nyrud, A.; Simonson, C.; and Tsunesugu, Y.) previously known to have published relevant topics. After that, the most relevant articles were chosen for more detailed evaluation. The decision to examine certain articles in more detail was based on the articles' titles and abstracts. Altogether, 265 publications were selected for further investigation.

During the search, the emphasis was on scientific articles and literature reviews published in peer-reviewed Englishlanguage journals. However, to gain a broader knowledge of the reviewed topics, relevant research reports, conference papers, books, and $\mathrm{PhD}$ dissertations were also included. In total, 140 publications between 1993 and 2019 were selected for inclusion in this review article after evaluation. Decisions in the evaluation were based on the completeness and quality of each study and its relevance to the studied subject. In addition to journal articles, the literature included six research reports, four conference papers, four Ph.D. dissertations, and three books.

The principal focus was on solid wood used in interior settings, such as panelled walls and ceilings, wooden floorings, furniture, and solid-wood structures that have wooden interior surface (e.g., timber walls). Wood-based and engineered wood products, as well as wood products with treatments (e.g., heat-treated wood) received less attention because their chemical composition and physical properties differ from solid wood products. Furthermore, even though they frequently are applied to wood in interior settings, different coatings (e.g., paints, varnishes and lacquers) were left out because they form a more or less permeable film on the wood surface that affects chemical and physical behaviour, as well as visual appearance. Furthermore, the properties of wood as a structural material (e.g., thermal insulation) were mainly excluded, even though they impact IEQ. However, solid wood structures were touched on in the chapter about acoustical properties because of their importance for completeness of acoustical environment and IEQ of a building.

\section{Results and discussion}

\subsection{Emissions of volatile organic compounds}

The emissions of volatile organic compounds (VOCs) from wood are an important factor in evaluating the impact of wood on IEQ. Wood consists primarily of cellulose, hemicellulose and lignin, but also contains several other organic and inorganic compounds (Schäfer and Roffael 2000). The composition and content of these compounds vary between tree species and growing locations, and additionally, 
variation within species and inside an individual tree can be substantial (Kirkeskov et al. 2009; Steckel et al. 2011). The bulk of VOC emissions occurs during wood's drying process, when most of the volatile compounds evaporate (Granström 2005). Generally, emissions decrease over time (Kirkeskov et al. 2009), but the emissions from freshly dried timber can be considerable (Steckel et al. 2011). Drying temperature impacts emission content, and ordinarily, with softwoods, which have a higher drying temperature, fewer terpene emissions are produced, compared with woods that have lower drying temperatures (Manninen et al. 2002; Hyttinen et al. 2010; Steckel et al. 2011). In addition, heat treatment significantly reduces VOC emissions of wood and changes their composition compared with air-dried wood samples (Manninen et al. 2002; Hyttinen et al. 2010). Heat treatment particularly decreases terpene emissions from Norway spruce (Picea abies) and Scots pine (Pinus sylvestris), as well as aldehyde emissions from European aspen (Populus tremula) (Hyttinen et al. 2010).

Softwoods are usually rich in extracts and, therefore, can release substantial amounts of VOCs, mainly terpenes and aldehydes (Risholm-Sundman et al. 1998; Manninen et al. 2002). Softwoods contain mostly mono- sesqui- and diterpenes (Granström 2005), and approximately $80 \%$ of VOC emissions from fresh softwood are monoterpenes (Hyttinen et al. 2010). The main terpenes found in emission from Scots pine and Norway spruce are monoterpenes $\alpha$-pinene, $\beta$-pinene, limonene and 3-carene (Risholm-Sundman et al. 1998; Hyttinen et al. 2010). The most abundant aldehyde compound in softwood emissions is hexanal (Risholm-Sundman et al. 1998; Manninen et al. 2002). Terpenes originate from the wood resin (Granström 2005; Widhalm et al. 2016), while aldehydes are secondary emissions formed from oxidation of unsaturated fatty acids (Risholm-Sundman et al. 1998; Steckel et al. 2011; Widhalm et al. 2016). Even though the main compounds emitted from pine and spruce are similar, it is important to notice that emitted amounts differ substantially and emissions from pine have been significantly higher compared to spruce (Hyttinen et al. 2010; VainioKaila et al. 2017b).

Emissions from hardwoods are notably lower than emissions from softwoods because of the absence of volatile terpenes (Pohleven et al. 2019). Softwood emissions provide a more versatile range of carbonyl compounds and alcohols (Risholm-Sundman et al. 1998). Aldehydes, especially hexanal and pentanal, are found in most hardwoods' emissions (Risholm-Sundman et al. 1998). Some species, such as European oak (Quercus robur), European beech (Fagus sylvatica) and black cherry (Prunus serotina), produce high emission of acetic acid, which is mainly formed from the hydrolysis of acetyl groups in hemicellulose (Risholm-Sundman et al. 1998; Gibson and Watt 2010). Additionally, lower amounts of corrosive formic acid is emitted from several hardwoods
(Gibson and Watt 2010). Most abundant emission products of wood from different tree species reported in the reviewed literature are presented in Table 1.

\subsubsection{Reported health effects from emission products}

Possible effects from emission products on IEQ fluctuate from odours to varying health effects on occupants. Several VOCs may have a pleasant or unpleasant smell, and their odour threshold is low enough to affect the perceived air quality (Wolkoff 2013). Often odour thresholds are several orders of magnitude lower than corresponding thresholds for sensory irritation, for example, the odour threshold of acetic acid threshold is more than 5000 times smaller than its threshold for sensory irritation (Wolkoff 2013). However, in addition to reduction in perceived IEQ by unpleasant odours from compounds in concentrations that are significantly lower than the thresholds for sensory irritation, they may possibly cause negative moods, stress, and environmental worry, which may result in physiological changes (Wolkoff 2013). Nonetheless, the issue between odours and health is complex and it is affected by personal attitudes and previous experiences (Wolkoff and Nielsen 2017).

In high concentrations, aldehydes can irritate eyes and mucous membranes, and various aldehydes cause odours even with minor concentrations (Risholm-Sundman et al. 1998). $\alpha, \beta$-Unsaturated aldehyde, acrolein, is a known pulmonary toxicant that acts synergistically with other carcinogens in the development of lung cancer, and is connected to the exacerbation of asthma in children (Seaman et al. 2007). Acrolein emissions have been measured from different species of lumber, such as Douglas fir (Pseudotsuga menziesii), pine (Pinus ponderosa and Pinus lambertiana), redwood (Sequoia sempervirens), "yellow poplar" (Liriodendron tulipifera), and red oak (Quercus rubra) (Seaman et al. 2007). Moreover, formaldehyde is a strong sensory irritant and classified as carcinogenic for humans by the International Agency for Research on Cancer (IARC) (Salthammer et al. 2010; Wolkoff 2013), and it is released from different wood species (Roffael 2006). With the exception of acrolein and formaldehyde, aldehydes are unlikely to cause sensory irritation because indoor air concentrations are typically orders of magnitude below the thresholds for sensory irritation (Wolkoff 2013).

Terpenes, the main emission product group from softwoods, provide several protective functions in trees (Granström 2005) and are mainly responsible for the typical smell of wood (Nore et al. 2017). The terpene group in conifers consists primarily of mono-, sesqui- and diterpenes (Granström 2010). The studies related to the terpenes' health effects mostly concern monoterpenes (e.g., $\alpha$-pinene, $\beta$-pinene, 3-carene and limonene) because of their volatile nature (boiling points of $150-180{ }^{\circ} \mathrm{C}$ ) and frequency in 
Table 1 Most abundant emission products of solid wood from different tree species

\begin{tabular}{lll}
\hline Species & Most abundant emission products & References \\
\hline Ash (Fraxinus excelsior) & Acetaldehyde, methanol, acetic acid, 2-pentylfuran & Risholm-Sundman et al. (1998) \\
& Acetaldehyde, propanal, hexanal, formaldehyde & Jensen et al. (2001) \\
Beech (Fagus sylvatica) & Hexanal, acetic acid, 2-pentylfuran, methanol & Risholm-Sundman et al. (1998) \\
& Hexanal, acetaldehyde, propanal & Jensen et al. (2001) \\
Birch (Betula pubescens) & Hexanal, pentanal, acetone, acetic acid & Risholm-Sundman et al. (1998) \\
European aspen (Populus tremula) & Hexanal, pentanal, acetic acid & Hyttinen et al. (2010) \\
Norway spruce (Picea abies) & $\alpha$-Pinene, $\beta$-pinene, hexanal, 3-carene & Risholm-Sundman et al. (1998) \\
& Acetaldehyde, hexanal & Jensen et al. (2001) \\
& $\alpha$-Pinene, limonene, $\beta$-pinene, acetic acid & Hyttinen et al. (2010) \\
Oak (Quercus robur) & Camphen, 3-carene, $\beta$-pinene & Vainio-Kaila et al. (2017b) \\
& Methanol, hexanal, acetic acid, 2-pentylfuran & Risholm-Sundman et al. (1998) \\
Scots pine (Pinus sylvestris) & Acetaldehyde, hexanal, propanal & Jensen et al. (2001) \\
& $\alpha$-Pinene, $\beta$-pinene, 3-carene, hexanal & Risholm-Sundman et al. (1998) \\
& $\alpha$-Pinene, 3-carene, hexanal & Jensen et al. (2001) \\
& $\alpha$-Pinene, 3-carene, hexanal & Manninen et al. (2002) \\
& $\alpha$-Pinene, 3-carene, hexanal & Hyttinen et al. (2010) \\
& $\alpha$-Pinene, 3-carene, pimaral & Bengtsson and Sanati (2004) \\
& $\alpha$-Pinene, 3-carene, $\beta$-pinene & Vainio-Kaila et al. (2017b) \\
\hline
\end{tabular}

indoor air (Granström 2010; Rohr 2013). Naturally, monoterpenes are found in the oleoresin of coniferous trees, and they are also used in various commercial products such as fragrances in cosmetics, food additives, solvents, medicines and household products (Kasanen et al. 1999). Reported health effects from exposure to terpenes are somewhat conflicting. In some of the studies reviewed by Kasanen et al. (1999), inhalation of terpenes has been noticed to irritate eyes and mucous membranes (Kasanen et al. 1999). However, harmful effects in real life situations have mainly been related to simultaneous exposure to high concentrations of several different terpenes, particularly among workers in wood-processing industry (Eriksson et al. 1997; Granström 2005, 2010). Alternatively, exposure to high concentrations of $\alpha$-pinene and 3 -carene (up to $1800 \mathrm{mg} / \mathrm{m}^{3}$ and $600 \mathrm{mg}$ / $\mathrm{m}^{3}$, respectively) did not elicit toxic effects on human lung cells (Gminski et al. 2010). Moreover, short-term exposure to concentrations of up to $13 \mathrm{mg} / \mathrm{m}^{3}$ of VOCs emitted from pinewood, predominantly $\alpha$-pinene and $\delta^{3}$-carene, did not induce sensory irritation or pulmonary effects in healthy humans (Gminski et al. 2011).

Short-term critical exposure limits (CELs) for $\alpha$-pinene and D-limonene were developed within the EPHECT project based on sensory irritation as the critical effect, and the values were $45 \mathrm{mg} / \mathrm{m}^{3}$ for $\alpha$-pinene and $90 \mathrm{mg} / \mathrm{m}^{3}$ for D-limonene (Trantallidi et al. 2015). Long-term CELs of $4.5 \mathrm{mg} / \mathrm{m}^{3}$ for $\alpha$-pinene and $9 \mathrm{mg} / \mathrm{m}^{3}$ for $\mathrm{D}$-limonene were derived, through extrapolation, from short-term data (Trantallidi et al. 2015). Although variation occurs among different building types, countries, and seasons, measured indoor air concentrations consistently have been significantly lower than these CEL values (Schlink et al. 2004; Geiss et al. 2011; Krol et al. 2014; Cometto-Muniz and Abraham 2015; Wang et al. 2017; Mandin et al. 2017). Due to concentrations in the lower $\mu \mathrm{g} / \mathrm{m}^{3}$ range measured indoors, monoterpenes alone are unlikely to cause sensory irritation in nonindustrial environments (Kasanen et al. 1999; Wolkoff and Nielsen 2017). However, odour thresholds, for example, for $\alpha$-pinene and D-limonene are significantly lower than their thresholds for sensory irritation (Wolkoff and Nielsen 2017). The measured indoor air concentrations have been close or above the odour thresholds, which may affect the perceived IEQ (Wolkoff and Nielsen 2017).

Terpenes have also been connected to psychological and physiological benefits. Exposure to volatile substances consisting mainly of terpenes has been found to enhance natural killer (NK) cells' activity in human immune system (Li et al. 2006, 2009). The results supported their other studies, in which similar findings in forest environments were reported ( $\mathrm{Li}$ et al. 2007, 2008). Inhalation of the sesquiterpene cedrol, extracted from cedar wood oil, increased parasympathetic nervous activity and decreased sympathetic activity, strongly suggesting that cedrol elicits a relaxant effect (Dayawansa et al. 2003). Similarly, it has been suggested that inhalation of VOCs emitted from Japanese cedar (Chamaecyparis obtusa), consisting mainly of sesquiterpenes, suppresses the activation of sympathetic nervous activity (Matsubara and Kawai 2014). Olfactory stimulation from monoterpene D-limonene induced physiological and psychological relaxation by decreasing heart 
rate, considerably increasing parasympathetic nervous activities, and generating a 'comfortable' feeling among the study subjects (Joung et al. 2014). Similarly, olfactory stimulation from $\alpha$-pinene induced physiological relaxation by increasing parasympathetic nervous activity and decreasing heart rate (Ikei et al. 2016).

\subsubsection{Terpene oxidation reactions}

Monoterpenes commonly found in softwood emissions (e.g. D-limonene, $\alpha$-pinene, $\beta$-pinene and 3-carene) are known for indoor gas-phase and surface reactions with ozone or other oxidants introduced from outside air or generated indoors by human activities (Weschler and Shields 1999; Wolkoff et al. 2000; Weschler 2004; Vartiainen et al. 2006; Uhde and Salthammer 2007; Wells et al. 2017; Salonen et al. 2018; Weschler and Carslaw 2018). These reactions form ultrafine particles and a complex mixture of chemical compounds (e.g., carbonyl compounds such as formaldehyde and carboxylic acids) (Weschler and Shields 1999; Glasius et al. 2000; Wolkoff et al. 2000; Nazaroff and Weschler 2004; Weschler 2004; Vartiainen et al. 2006; Wolkoff and Nielsen 2017). The reactions occur when the reaction time of the chemicals is faster than or comparable to the air exchange rate of the indoor settings (Weschler and Shields 1999). Varying indoor conditions, such as relative humidity, reaction time, and chemical composition of indoor air, affect the nature and concentration of oxidation products (Fick et al. 2003; Weschler 2004). The reaction products from the oxidation of monoterpenes have been shown to cause upper-airway irritation in animal bioassay experiments (Wolkoff et al. 2000, 2013; Rohr et al. 2002; Wilkins et al. 2003). In addition, short-term perceived indoor air quality has been found to be poorer in a room with higher end of realistic concentrations of ozone and limonene, compared with situations in which only ozone or limonene was present (Tamás et al. 2006). However, literature research on terpene oxidation products' health effects concluded that even though many gas-phase reaction products have a high irritant potency, the health effects remain unclear at more environmentally relevant concentrations (Rohr 2013). Furthermore, Wolkoff and Nielsen (2017) summarized in their study that based on human and rodent exposure studies, measured levels of key oxidation products in offices are too low for causing airflow limitation and sensory irritation (Wolkoff and Nielsen 2017). Furthermore, it has been demonstrated in mice inhalation models of allergic inflammation that D-limonene alone (Hirota et al. 2012; Bibi et al. 2015) and in ozone/D-limonene system (Hansen et al. 2013, 2016) has anti-inflammatory effects.

\subsection{Moisture buffering effect}

Relative humidity (RH) of indoor air mainly results from outdoor air moisture content, ventilation rate, and interior sources of moisture (people, activities etc.). Indoor humidity affects thermal and respiratory comfort, perceived air quality, durability of materials, and energy consumption (Simonson et al. 2002; Salonvaara et al. 2004; Osanyintola and Simonson 2006; Yang et al. 2012). The most favourable range for indoor $\mathrm{RH}$ when considering health and hygiene is between 30 and 55\% (Simonson et al. 2001). Indoor moisture control is carried out mostly with ventilation, but indoor environment's moisture behaviour is also affected by moisture buffering effects from hygroscopic materials used on the interior surfaces of the building envelope and furniture (Kunzel et al. 2004; Svennberg et al. 2004). The moisture buffering effect is based on absorption and desorption of water vapour as a consequence of humidity variations in surrounding air (Hameury and Lundström 2004). Hygroscopic surface materials that are exposed to the indoor environment absorb moisture when indoor RH increases, and desorb moisture back to indoor air when the RH decreases (Svennberg et al. 2004; Hedegaard et al. 2005). To moderate diurnal variations in indoor environment's RH level with less energy-intensive methods, hygroscopic materials have a potential to help control indoor air humidity by minimising peak variations, thereby reducing periods with both very high and very low relative humidity (Svennberg et al. 2004; Osanyintola and Simonson 2006; Yang et al. 2012).

The efficiency of the moisture buffering effect of the material depends on the surface area's exposure to indoor air, vapour permeability, coating, sorption capacity, diffusion coefficient, and active thickness (Koponen 2004; Osanyintola and Simonson 2006). In addition, ventilation rate and moisture load it transfers are important factors, as the ventilation rate governs the mean level of indoor $\mathrm{RH}$, and the moisture buffering performance only affects the amplitude of the RH variations (Hedegaard et al. 2005). Increased ventilation rate decreases the effects of the hygroscopic materials, but with higher moisture loads, their effects increase (Simonson et al. 2002). Li et al. (2012) observed the effect of ventilation in a large-scale experimental study, and it was noticed that at a constant moisture generation rate $(42 \mathrm{~g} / \mathrm{h})$ increasing the ventilation rate from 0.5 air changes per hour $(\mathrm{ACH})$ to $0.75 \mathrm{ACH}$ decreased indoor RH by $4 \%$, of which $1 \%$ is caused by the room's wood panelling. They concluded that within the used moisture generation rates $(42-58.5 \mathrm{~g} / \mathrm{h}$ ) and air exchange rates $(0.5-0.75 \mathrm{ACH})$, these factors caused up to $8 \%$ variation in $\mathrm{RH}$ levels, and the wood panelling was able to moderate these variations by up to $30 \%$. 


\subsubsection{Moisture buffering properties of wood}

The moisture buffering properties of wood vary between different species and the direction towards indoor air (Svennberg 2006). Softwood's moisture permeability often is lower than that of hardwood (Svennberg 2006). The moisture buffering capacity of wood is superior in longitudinal direction compared with other construction materials, but low moisture diffusion in transverse direction, in which interior wood is normally used, inhibits deeper moisture penetration (Koponen 2004; Hameury 2005). In the transverse direction, the penetration depth of moisture is roughly $1 \mathrm{~mm}$ for daily humidity cycles (Hameury 2005). Although the wood's hygroscopic properties towards the transverse direction are less impressive, the moisture buffering performance of untreated spruce panels has been found to be significantly higher compared with other commonly used building materials, such as brick, concrete and gypsum board (Rode et al. 2005). In a room with low ventilation and a large surface area of wood exposed to surrounding humidity, the buffering effect forms a considerable factor (Hameury 2005). In similar settings, according to research results, it is possible to reduce the daily humidity fluctuations of indoor air and improve the perceived air quality without increasing the amount of ventilation (Simonson et al. 2001, 2002; Kunzel et al. 2004; Hameury 2005; Kurnitski et al. 2007; Li et al. 2012; Nore et al. 2017). For example, a hygroscopic structure with wood-based materials has the potential to reduce the maximum RH of indoor air by up to $35 \%$, compared with a non-hygroscopic structure (Simonson et al. 2002). In addition, it is expected that hygroscopic dividers, internal walls, and furniture could also be beneficial in office-like buildings with higher ventilation rates (Simonson et al. 2002).

\subsubsection{Latent heat exchange}

Moisture transfer between indoor air and hygroscopic materials also affects the indoor temperature because of the conversion of latent heat (Hameury 2005; Kraniotis et al. 2016; Nore et al. 2017). Due to the phase change that humidity undergoes during the process of moisture exchange between hygroscopic material and surrounding air, wood temperature increases when moisture is absorbed and decreases during drying (Simonson et al. 2002; Hameury 2005; Kraniotis et al. 2016). This leads to the possibility of reducing energy needed to heat, cool and ventilate buildings, especially in tandem with a well-controlled HVAC system (Osanyintola and Simonson 2006; Nore et al. 2017). The numerical model by Osanyintola and Simonson (2006) for a bedroom with wood-based structural components and occupation at night showed that it is possible to reduce energy consumption together with hygroscopic materials and an optimally controlled HVAC system. The study concluded that potential energy savings are the highest for buildings in hot and humid climate with mechanical cooling equipment, but energy saving seems possible in all climates. Direct energy savings were estimated to be $2-3 \%$ for total heating energy and $5-30 \%$ for total cooling energy. Potential indirect savings from reduced ventilation rate and indoor temperature, while maintaining acceptable indoor air quality and comfort, were around 5\% for heating and between 5-20\% for cooling. Nonetheless, it should be noted that results from simulations and numerical models might not consider all relevant factors (e.g., window airing and furnishings), which can even out the differences between hygroscopic and non-hygroscopic materials in real-life situations for both energy savings and indoor air quality (Kurnitski et al. 2007). However, Nore et al. (2017) studied the use of wooden surfaces compared to non-hygroscopic surface materials in bathrooms with two test houses and hygrothermal simulation software. They found out that the software was quite accurate for the nonhygroscopic case, but there existed more discrepancy in the hygroscopic case for indoor RH and surface temperature. According to their test house measurements, heat demand to maintain same temperature levels decreased with wood surfaces, and they calculated potential annual heat savings of $36.5 \%$ and $45 \%$ for a bathroom located in Oslo and Troms $\varnothing$, Norway.

\subsubsection{Moisture buffering in building design}

Benefitting from the moisture buffering capacity of wood and other materials is rather complicated because moisture migration is associated with various physical phenomena, for example, molecular vapour diffusion, capillary flow, evaporation and condensation (Abadie and Mendonca 2009; Yang et al. 2012). Thus, it is not easily quantifiable and generally neglected in the design and operation of buildings. To characterise the materials' moisture buffering capacity and help designers factor it into construction, the NORDTEST Project created a moisture buffering value (MBV), which can be used to appraise the materials' moisture buffering quality (Rode et al. 2005). The project also provided a test protocol on how to determine experimentally MBV of materials and systems (Rode et al. 2005). MBV denotes the amount of moisture absorbed and released by a material during humidity changes in surrounding air, and it can be applied to design practices to compare different moisture buffering properties of the materials (Rode et al. 2005). However, moisture buffering performance on a room level is affected by factors such as ventilation conditions and moisture generation, which must be acknowledged during the design process; thus, these material buffering properties alone may not be directly representative when designing indoor environments ( $\mathrm{Li}$ et al. 2012). 


\subsection{Antibacterial effects}

The hygienic properties of indoor surfaces are of special interest in certain environments, such as health care facilities, schools, and day-care centres. Understanding the materials' microbial properties is important to prevent infections from spreading throughout contaminated surfaces (VainioKaila 2017). Continuous debate about wood's hygienic properties has existed since the 1960s, and consequently, in many sectors, wood is viewed critically (Milling et al. 2005a). However, more recent studies suggest that wood has antibacterial properties.

The antibacterial properties of wood have been studied particularly from the perspective of the food industry, and it has been found that several wood species inhibit bacterial survival compared with plastic (Ak et al. 1994a, b; Gehrig et al. 2000; Schönwalder et al. 2002; Milling et al. 2005a, b; Filip et al. 2012). However, antibacterial properties fluctuate significantly among woods from different tree species. Strong antibacterial activity has been detected in Scots pine (Pinus sylvestris) (Schönwalder et al. 2002; Milling et al. 2005a, b; Laireiter et al. 2013; Vainio-Kaila 2017) and European oak (Quercus robur) (Milling et al. 2005a). European larch (Larix decidua) wood (Schönwalder et al. 2002; Milling et al. 2005a; Kavian-Jahromi et al. 2015) and bark (Laireiter et al. 2013) have exhibited antibacterial characteristics, though variations in results have been reported among different studies. Similarly, Norway spruce (Picea abies) has demonstrated antibacterial effects (Milling et al. 2005a; Vainio-Kaila et al. 2013; Vainio-Kaila 2017), but the results are more varied, and spruce repeatedly has shown weaker hygienic performance compared with pine (Schönwalder et al. 2002; Milling et al. 2005a; Vainio-Kaila 2017). Furthermore, antibacterial activity has been found in other species including ash, basswood, beech, birch, butternut, cherry, hard maple and black walnut (Ak et al. 1994a, b). A summary of the antibacterial effects of different species is presented in Table 2.

In some of these studies, different parts of wood have been observed separately. Laireiter et al. (2013) investigated the antibacterial effects of Scots pine sap- and heartwood, and European larch sap-, heart-, knot-wood, and bark using four bacterial strains. Pine sapwood did not demonstrate antibacterial effects against the bacterial strains tested,

Table 2 Antibacterial effects of different woods on certain bacterial strains

\begin{tabular}{|c|c|c|c|}
\hline Species (HW/SW) & Samples & Bacteria $(\mathrm{Gram}+/-)$ & References \\
\hline Beech, Birch, Maple & Wood blocks & Escherichia coli (-) & Ak et al. (1994a) \\
\hline Basswood, Maple & Wood blocks & Listeria monocytogenes $(+)$ & \\
\hline Birch, Maple & Wood blocks & Salmonella typhimurium (-) & \\
\hline Scots pine (HW), Larch & Wood boards & Escherichia coli (-) & Schönwalder et al. (2002) \\
\hline Scots pine $(\mathrm{HW})$ & Wood boards & Enterococcus faecium $(+)$ & \\
\hline Oak, Scots pine (mixed HW and SW) & Wood sawdust & Escherichia coli $(-)$ & Milling et al. (2005a) \\
\hline Oak, Larch, Scots pine (mixed HW and SW) & Wood sawdust & Enterococcus faecium $(+)$ & \\
\hline Scots pine $(\mathrm{HW})$ & Wood cylinders & $\begin{array}{l}\text { Escherichia coli }(-), \text { Listeria } \\
\text { monocytogenes }(+)\end{array}$ & Vainio-Kaila et al. (2011) \\
\hline Larch bark, Scots pine (HW) & Wood discs, extracts (methanol) & Staphylococcus aureus $(+)$ & Laireiter et al. (2013) \\
\hline Scots pine (HW) & Wood discs, extracts (methanol) & Enterococcus faecium (+) & \\
\hline Scots pine $(\mathrm{HW})$ & Wood discs, extracts (methanol) & Bacillus subtilis (+) & \\
\hline Scots pine (HW and SW), Norway spruce & $\begin{array}{l}\text { Wood cylinders (untreated, heat } \\
\text { treated, extracted) }\end{array}$ & Escherichia coli (-) & Vainio-Kaila et al. (2013) \\
\hline Larch (HW and SW) & Wood cubes and shavings & Staphylococcus aureus $(+)$ & Kavian-Jahromi et al. (2015) \\
\hline Larch (HW and SW) & Wood cubes and shavings & Klebsiella pneumoniae (-) & \\
\hline Scots pine (HW and SW), Norway spruce & Extracts (acetone) & Staphylococcus aureus (+) & Vainio-Kaila et al. (2015) \\
\hline Scots pine (HW and SW) & Extracts (acetone) & Enterococcus faecalis $(+)$ & \\
\hline Scots pine (SW) & Extracts (acetone) & Escherichia coli (-) & \\
\hline Scots pine (HW and SW), Norway spruce & Extracts (acetone) & Streptococcus pneumonia $(+)$ & \\
\hline $\begin{array}{l}\text { Scots pine (HW and SW), Norway spruce } \\
\text { (HW) }\end{array}$ & Extracts (acetone) & Staphylococcus aureus (+) & Vainio-Kaila et al. (2017a) \\
\hline Scots pine $(\mathrm{HW})$ & Extracts (acetone) & Escherichia coli (-) & \\
\hline Scots pine (SW), Norway spruce (HW and SW) & Emitted VOCs (gaseous) & Streptococcus pneumoniae $(+)$ & Vainio-Kaila et al. (2017b) \\
\hline $\begin{array}{l}\text { Scots pine (HW and SW), Norway spruce (HW } \\
\text { and SW) }\end{array}$ & Emitted VOCs (gaseous) & Escherichia coli $(-)$ & \\
\hline
\end{tabular}

Heartwood (HW) and sapwood (SW) marked if it has been reported 
whereas pine heartwood demonstrated definite antibacterial effect on three Gram-positive bacterial strains ( $S$. aureus, B. subtilis and E. faecium). However, pine heartwood had no effect on the only Gram-negative bacterial strain, $P$. aeruginosa. Sap-, heart- and knot-wood of larch had no antibacterial effect on any of the four bacterial strains. Larch bark inhibited the growth of $S$. aureus, though strong variety existed in the detected inhibiting zones and the effect was not observed on all of the bark samples tested. Kavian-Jahromi et al. (2015) studied the antibacterial effects of larch sap- and heartwood on one Gram-negative bacterial strain (K. pneumoniae) and on one Gram-positive strain (S. aureus, MRSA). The results clashed with those of Laireiter et al. (2013), significant reductions in plate counts for both bacterial strains were detected in both heart- and sapwood samples of larch. Vainio-Kaila et al. (2013) examined the antibacterial effects of sap- and heartwood from Scots pine on a Gram-negative bacterial strain E. coli. They found that both sap- and heartwood exhibited antibacterial action and performed better than glass. Contrary to results from Laireiter et al. (2013), pine sapwood demonstrated faster decreases in bacterial counts than heartwood.

\subsubsection{Factors affecting antibacterial effects}

The mechanisms behind the antibacterial activity of wood are not completely understood, but it is believed to derive from a combination of factors such as hygroscopic drying of the wood surface and wood extractives (Schönwalder et al. 2002; Vainio-Kaila et al. 2011). Hygroscopicity is associated with dehydration of bacteria, and some of the chemical components in wood directly inhibit the growth of bacteria (Schönwalder et al. 2002; Vainio-Kaila et al. 2011; Laireiter et al. 2013). The role of extractives and other wood components in antibacterial activity has been investigated in a few studies, and it has been found that the extracts from pine heartwood (Laireiter et al. 2013; Vainio-Kaila et al. 2015, 2017a), sapwood and spruce heartwood (Vainio-Kaila et al. 2015, 2017a) inhibit the growth of several Gram-positive bacterial strains. Extracts from pine sapwood (Vainio-Kaila et al. 2015) and heartwood (Vainio-Kaila et al. 2017a) have been found to inhibit growth of Gram-negative strain E. coli. Knotwood extracts from different Pinus species have demonstrated antibacterial effects on several Gram-positive bacterial strains and the antibacterial properties correlated with the extracts' stilbene content (Välimaa et al. 2007). Resin salve made from Norway spruce has been found to exhibit antibacterial effects on several Gram-positive bacteria and on the Gram-negative strain P. vulgaris (Rautio et al. 2007). Milled wood lignin from spruce sawdust exhibited an antibacterial effect on the Gram-positive strain S. aureus (Vainio-Kaila et al. 2017a). Furthermore,
Vainio-Kaila et al. (2013) noticed that altering extractive content through heat treatment or extraction with acetone decreased the antibacterial effect of wooden samples made from pine sapwood and heartwood, and spruce sapwood.

Vainio-Kaila et al. (2017b) studied the antibacterial effect of volatile organic compounds emitted from milled heartwood and sapwood of Scots pine and Norway spruce. They noticed that VOCs induced antibacterial effects on E. coli and Gram-positive strain S. pneumonia, and had a slight effect on the Gram-negative strain S. typhimurium. The effect on $S$. aureus was small, even after incubation for three days. A stronger effect was generally noticed with dry wood particles, compared with wet particles. The largest chemical group in VOC emissions from all wood species was monoterpenes, and the most dominant terpene was $\alpha$-pinene. Additionally, the terpenes $\alpha$-pinene and limonene were tested separately. It was noticed that $\alpha$-pinene elicited a strong effect on S. pneumonia and some effect on S. typhimurium. Limonene strongly inhibited the growth of S. pneumonia and E. coli.

Variability in the antibacterial effects of wood has been noticed by their effect on different bacterial strains, which can be divided into two groups based on differences in the cell wall structure: Gram-positive and Gram-negative (Vainio-Kaila 2017). Gram-positive bacteria have more layers in their cell walls than Gram-negative bacteria, and it has been thought that this could provide more protection for Gram-positive bacteria against wood's antibacterial properties (Schönwalder et al. 2002; Milling et al. 2005a; Kavian-Jahromi et al. 2015). However, some studies have found Gram-positive bacteria to be more sensitive (Laireiter et al. 2013; Vainio-Kaila et al. 2015, 2017a).

Other factors influencing wood's antibacterial effects include ambient temperature and humidity, and the moisture content of wood (Milling et al. 2005a). Increased humidity and moisture content delayed reductions in bacteria, and higher temperatures accelerated bacteria's dying process (Milling et al. 2005a). However, the effect of humidity depends on the bacterial species and other factors, and both very high humidity and very low humidity have been found to reduce the bacteria's survival time on various surfaces (Vainio-Kaila et al. 2017b).

It has also been discussed how aging of wood affects its antibacterial properties: As volatile compounds evaporate, the chemical composition of wood changes and wooden surfaces degrade over time (Vainio-Kaila 2017). Most of the reviewed studies used new wood, so effects from aging have not been studied extensively and more research is needed to examine how the antibacterial properties develop over time. However, two studies that compared old and new cutting boards noticed that antibacterial effects were independent of the wood's age (Ak et al. 1994a; Schönwalder et al. 2002). 


\subsection{Acoustic properties}

Room acoustics are in the centre of attention when considering acoustics and wooden interior materials. Acoustics in a room or space are determined by how sound waves are affected when they hit walls, ceiling, floor, furniture, and other objects. These encounters control propagation, reflection, and attenuation of sound within a space. Surface materials are significant factors in room acoustics, and they should be selected depending on the purpose of use of the room: for speech and music listening, offices, industrial buildings, homes, etc. (Bucur 1995).

Across the audible spectrum, sound absorption and sound reflection efficiency are affected greatly for example by the material's internal structure, surface treatment, type of mounting, and geometry (Bucur 1995). Wood has a relatively low sound absorption coefficient and is considered as sound reflecting material (Kang et al. 2010), and the sound conducting properties of wood are better in the longitudinal grain direction compared to the perpendicular direction (Asdrubali et al. 2017). Therefore, dense wooden structures are commonly used to build surfaces that channel sound reflections, for example, in musical instruments and concert halls (Asdrubali et al. 2017). The main properties affecting wood's sound absorption capabilities include airflow resistance, which varies according to the sound incident surface structure, and pore characteristics (Kang et al. 2008). Wood has numerous cylindrical pores in fibre direction due to its ecological structure, and wood's sound absorption can be classified as porous absorption (Kang et al. 2008, 2010). In porous absorption, when sound waves enter into cavities of porous material, internal friction or viscous resistance of the cavity wall converts part of the sound energy into thermal energy (Kang et al. 2008). However, a small number of continuous pores reduce wood's permeability, resulting in a low sound absorption coefficient (Kang et al. 2010).

The sound absorption properties of wood have been improved with multi-layered constructions: forming a socalled board resonator by placing porous absorption material with an air gap behind the board or panelling (Asdrubali et al. 2017). When the resonator vibrates, it effectively dampens low-frequency sounds (Asdrubali et al. 2017). To enhance the dampening effect of medium-to-high frequencies, a perforated resonator can be made by making holes or wooden battening on the wooden surface (Asdrubali et al. 2017). In addition, the sound absorbing capability of wood has been enhanced by improving the permeability through different treatments (Kang et al. 2008, 2010) or by producing wood composites from fibrous materials (Smardzewski et al. 2014, 2015).

\subsubsection{Sound insulation of wood}

In some cases (e.g. timber construction), wood is simultaneously interior surface material and structural material, and it is essential to consider its sound insulation performance. Especially at lower frequencies, the weight of the material is an important factor, so the sound insulation performance of light materials, like wood, is not particularly good (Forssen et al. 2008). However, the airborne sound insulation of solid wood elements at lower frequencies is better than that of lighter wood frame elements, but higher frequencies may be problematic for solid wood elements (Forssen et al. 2008). The sound insulation performance of solid wooden walls can be enhanced, for instance, with properly designed double constructions (Forssen et al. 2008).

Similarly, impact sound insulation from people walking and airborne sound insulation are common issues for massive wooden floors especially at low frequencies (Martins et al. 2015). It is possible to achieve significantly better sound insulation with self-supporting suspended ceilings that have no structural contact with the floor (Forssen et al. 2008) Sound insulation can also be improved by using different timber-concrete composite solutions (Martins et al. 2015). However, to fulfil the acoustic requirements completely, a suspended ceiling might be necessary with the composite solutions (Martins et al. 2015).

\subsection{Psychological and physiological effects of wood}

Nyrud and Bringslimark (2010) did an extensive literature review on psychological responses from wood. They noticed that the existing research on the topic generally concerned three different outcomes: (1) perception of wood, including both visual perception and tactile sensation; (2) attitudes and preferences (aesthetic evaluation) of various wood products; and (3) emotional and psychophysiological responses from wood. They stated that even though these responses are closely related to each other, they are commonly separated in psychological literature, and it is important to consider them all to understand possible psychological benefits of interior wood use.

According to Nyrud and Bringslimark (2010), several factors affect the visual impression of wood, including species, number of knots, colour, structure and surface treatment. In particular, people focus on a mixture of five surface features when they look at wood: texture, knots, coloration, contrasts, and other properties (e.g., pitch wood, pitch pockets, and bark pockets) (Broman 1995). Generally, homogenous visual properties and surface harmony (e.g., only a few evenly dispersed knots on wood surface are perceived as desired aesthetic properties) (Broman 2001; Hoibo and Nyrud 2010). 
People commonly have positive attitudes towards wood and perceive it as a natural material that evokes feelings of comfort, relaxation, and warmth (Rice et al. 2006; Burnard and Kutnar 2015; Watchman et al. 2017). The perception of warmth has been associated with the yellow-red colour hue, while the knots create a natural and rustic appearance (Rice et al. 2006). Solid wood samples (with stone and brick) are consistently considered more natural than engineered woodbased products or building materials with greater degrees of transformation, such as metal, plastic and fabric (Burnard et al. 2017). Furthermore, wood is generally preferred when compared with other building materials (Rice et al. 2006; Spetic et al. 2007; Zhang et al. 2016; Watchman et al. 2017; Dematte et al. 2018) and wood-based products (Jonsson et al. 2008; Lindberg et al. 2013). However, the results of some studies indicate that the level of used interior wood is an important factor and that rooms with intermediate levels of wood are preferred over rooms with no wood or extensive use of wood (Tsunetsugu et al. 2007; Nyrud et al. 2014; Dematte et al. 2018).

Even though most information about the physical environment is gathered through vision, in indoor environments, people frequently touch wooden surfaces and other materials, for example, interior applications and furniture (Lindberg et al. 2013), and this tactile sensation of wood has been observed in a few studies. In one survey, participants evaluated different floorings with their hands and feet: Parquet flooring with 'natural' oiled surface was perceived as warm, rough and fairly soft, and it generally was preferred over laminate flooring and parquet flooring with lacquer (Berger et al. 2006). Bhatta et al. (2017) studied how the sensory and emotional aspects of touch with fingertip are related to eight different types of surfaces from Scots pine and oak wood boards with four types of treatments (sanding with sandpaper, brushing with metal brush, varnish and wax) applied to each species. Natural (uncoated) wood surfaces were rated significantly higher in descriptors that feature positive aspects of emotional components and least irritating and uncomfortable in descriptors that feature the negative aspects of affective touch. Similar results were attained in a study by Lindberg et al. (2013), in which tactile sensations from solid wood samples from different species were perceived as natural and eco-friendly. A greater variation in terms of perceived attributes existed among the studied wood-composite materials, but they generally scored low on naturalness and exclusivity.

\subsubsection{Physiological effects from wood derived stimuli}

Psychophysiological responses are physiological responses (such as stress responses) to external stimuli, and by measuring these responses, it is possible to evaluate outcomes on psychological and physical well-being from encounters with wood (Nyrud and Bringslimark 2010). Physiological responses act as indicators of human stress, and common indices used to evaluate these responses include brain activity, autonomic nervous activity, endocrine activity, and immune system activity (Burnard and Kutnar 2015; Ikei et al. 2017). Research on the physiological effects of wood is relatively new, but a growing number of studies related to the topic now exist. Physiological effects from wood-derived stimulation studied through physiological indices have concentrated on olfactory, visual, auditory and tactile sensations (Ikei et al. 2017). In this section, the studies related to tactile and visual sensations are reviewed, and a summary of findings is presented in Table 3. Studies related to physiological effects from stimulations of olfactory sensation are presented in the section of this review about chemical emissions. The two studies found to examine the stimulation of auditory sensation mainly concerned physiological responses related to floor-impact sound insulation and were left out of this review (Sueyoshi et al. 2004a, b).

Morikawa et al. (1998) studied the influence of contact with wood (Japanese cypress (Cryptomeria japonica) with a sawn surface and Japanese cedar (Chamaecyparis obtusa) with a planed and sawn surface), silk, denim, a stainlesssteel board and a vinyl bag filled with cold water. Nineteen female subjects touched the materials for $60 \mathrm{~s}$ while their pulse rate and systolic blood pressure were measured. The study showed that contact with silk and wood with a sawn surface caused small variations in pulse rate and systolic blood pressure. In contrast, fluctuations were wide for both measures during contact with the stainless steel and the vinyl bag filled with water.

Sakuragawa et al. (2008) examined the effects from contact with wood (Japanese cypress and Japanese cedar), plastic, and aluminium using subjective evaluation and blood pressure as an indication of physiological stress responses. They found that contact with wood produced safe/comfortable and coarse/natural sensations, and that contact with cooled wood produced similar coarse/natural sensation with a subjectively dangerous/uncomfortable sensation. Contact with wood caused no increase in blood pressure, but contact with aluminium or cold acrylic plastic produced flat/artificial and dangerous/uncomfortable sensations with increased systolic blood pressure.

Tsunetsugu et al. $(2002,2005,2007)$ investigated physiological responses to wood in three studies using actualsize model rooms. In the first study, one of the rooms was a 'standard' Japanese living room with a wooden floor and papered walls and ceiling. The second room was identical except for wooden beams and columns that were added. Ten male subjects were exposed to test rooms for $90 \mathrm{~s}$ while their blood pressure and pulse rate were measured. In addition, the subjects evaluated the rooms subjectively and their temporal mood states were examined. Decreased blood 
Table 3 Summary of the physiological effects of wood on visual and tactile sensations

\begin{tabular}{|c|c|c|c|c|}
\hline Physiological indices & Main findings & Stimulation (time) & Participants & References \\
\hline Autonomic nervous activity & $\begin{array}{l}\text { Pulse rate and systolic blood } \\
\text { pressure: } \\
\text { Small fluctuation with silk and } \\
\text { sawn wood } \\
\text { Large fluctuation with steel and } \\
\text { vinyl bag }\end{array}$ & $\begin{array}{l}\text { Japanese cypress (sawn), Japa- } \\
\text { nese cedar (sawn, planed), silk, } \\
\text { denim, stainless steel, vinyl bag } \\
\text { Tactile sensation }(60 \mathrm{~s})\end{array}$ & $\begin{array}{l}\text { Female students } \\
\mathrm{n}=19\end{array}$ & $\begin{array}{l}\text { Morikawa et al. } \\
\text { (1998) }\end{array}$ \\
\hline Autonomic nervous activity & $\begin{array}{l}\text { Pulse rate: } \\
\text { Decrease in standard room } \\
\text { Increased in designed room } \\
\text { Diastolic blood pressure: } \\
\text { Decreased in standard room }\end{array}$ & $\begin{array}{l}\text { "Standard" room with wood and } \\
\text { "designed" room with added } \\
\text { wooden elements }(90 \mathrm{~s})\end{array}$ & $\begin{array}{l}\text { Male students } \\
\quad \mathrm{n}=10\end{array}$ & $\begin{array}{l}\text { Tsunetsugu et al. } \\
\text { (2002) }\end{array}$ \\
\hline Autonomic nervous activity & $\begin{array}{l}\text { Pulse rate: } \\
\text { Decrease in standard room } \\
\text { Increased in designed room } \\
\text { Diastolic blood pressure: } \\
\text { Decreased in standard room }\end{array}$ & $\begin{array}{l}\text { "Standard" room with wood and } \\
\text { "designed" room with added } \\
\text { wooden elements }(90 \mathrm{~s})\end{array}$ & $\begin{array}{l}\text { Male students } \\
\quad \mathrm{n}=15\end{array}$ & $\begin{array}{l}\text { Tsunetsugu et al. } \\
\text { (2005) }\end{array}$ \\
\hline Brain activity & $\begin{array}{l}\text { Regional cerebral blood flow } \\
\text { (rCBF): } \\
\text { Increased in standard and } \\
\text { designed room }\end{array}$ & & & \\
\hline Autonomic nervous activity & $\begin{array}{l}\text { Pulse rate: } \\
\text { Increased in } 45 \% \text { room } \\
\text { No change in } 0 \% \text { and } 90 \% \text { rooms } \\
\text { Diastolic blood pressure: } \\
\text { Decreased in all rooms } \\
\text { Systolic blood pressure: } \\
\text { Decreased in } 90 \% \text { room }\end{array}$ & $\begin{array}{l}\text { Rooms with surface wood ratios: } \\
0 \%, 45 \%, 90 \% \text { (90 s) }\end{array}$ & $\begin{array}{l}\text { Male students } \\
\mathrm{n}=15\end{array}$ & $\begin{array}{l}\text { Tsunetsugu et al. } \\
\text { (2007) }\end{array}$ \\
\hline Brain activity & $\begin{array}{l}\text { Changes in total haemoglobin } \\
\text { concentration }(\mathrm{tHb}) \text { : } \\
\text { Increased in all rooms }\end{array}$ & & & \\
\hline Autonomic nervous activity & $\begin{array}{l}\text { Systolic blood pressure: } \\
\text { Exposure to cypress panels } \\
\text { Decreased in "like" group } \\
n=5 \\
\text { No change in "dislike" group } \\
n=5 \\
\text { Exposure to steel panels } \\
\text { Increased in "dislike" group } \\
n=9\end{array}$ & $\begin{array}{c}\text { Full sized wall panels: Japanese } \\
\text { cypress and white steel (90 s) }\end{array}$ & $\begin{array}{l}\text { Male students } \\
\mathrm{n}=14\end{array}$ & $\begin{array}{l}\text { Sakuragawa et al. } \\
\text { (2005) }\end{array}$ \\
\hline Autonomic nervous activity & $\begin{array}{l}\text { Systolic blood pressure: } \\
\text { Increased with aluminium and } \\
\text { cold plastic } \\
\text { No change with cypress, cedar } \\
\text { and oak }\end{array}$ & $\begin{array}{l}\text { Japanese cypress, Japanese cedar, } \\
\text { oak, acrylic plastic, aluminium } \\
\text { (cool, room temp., hot) } \\
\text { Tactile sensation }(60 \mathrm{~s})\end{array}$ & $\begin{array}{l}\text { Male students } \\
\mathrm{n}=13\end{array}$ & $\begin{array}{l}\text { Sakuragawa et al. } \\
\text { (2008) }\end{array}$ \\
\hline Endocrine activity & $\begin{array}{l}\text { Plasma cortisol levels: } \\
\text { Decreased in redecorated room }\end{array}$ & $\begin{array}{l}\text { Hospital isolation rooms: "stand- } \\
\text { ard" and redecorated with wood } \\
\text { panels and rice paper }(26 \mathrm{~h})\end{array}$ & $\begin{array}{l}\text { Male students } \\
\mathrm{n}=7\end{array}$ & $\begin{array}{l}\text { Ohta et al. } \\
\text { (2008) }\end{array}$ \\
\hline Autonomic nervous activity & $\begin{array}{l}\text { Frequency of non-specific skin } \\
\text { conductance responses } \\
\text { (F-NS-SCR): } \\
\text { Decreased in wood environments } \\
\text { No effects regarding plants }\end{array}$ & $\begin{array}{l}\text { Four office environments: no } \\
\text { plants and no wood, plants with } \\
\text { no wood, no plants and wood, } \\
\text { plants with wood (40 min) }\end{array}$ & $\begin{array}{l}\text { University } \\
\text { students } \\
\mathrm{n}=119\end{array}$ & $\begin{array}{l}\text { Fell } \\
\quad(2010)\end{array}$ \\
\hline Autonomic nervous activity & $\begin{array}{l}\text { Systolic blood pressure: } \\
\text { Lower in wooden rooms } \\
\text { Ratio of heart rate variability: } \\
\text { Lower in wooden rooms } \\
\text { Oxyhemoglobin saturation } \mathrm{SpO}_{2} \text { : } \\
\text { Higher in wooden rooms }\end{array}$ & $\begin{array}{l}\text { Five test rooms: non-wooden } \\
\text { preparation and test rooms, and } \\
3 \text { wooden rooms with different } \\
\text { contrast }(60 \mathrm{~min})\end{array}$ & $\begin{array}{l}\text { Adult subjects } \\
\mathrm{n}=20\end{array}$ & $\begin{array}{l}\text { Zhang et al. } \\
\text { (2017) }\end{array}$ \\
\hline
\end{tabular}


Table 3 (continued)

\begin{tabular}{|c|c|c|c|c|}
\hline Physiological indices & Main findings & Stimulation (time) & Participants & References \\
\hline Autonomic nervous activity & $\begin{array}{l}\text { Salivary free cortisol concentra- } \\
\text { tion: } \\
\text { Decreased in oak environment }\end{array}$ & $\begin{array}{l}\text { Four test settings: offices with oak } \\
\text { and walnut furniture and control } \\
\text { offices with no wood ( } 75 \mathrm{~min})\end{array}$ & $\begin{array}{l}\text { Adult subjects } \\
\mathrm{n}=61\end{array}$ & $\begin{array}{l}\text { Burnard and Kutnar } \\
\text { (2019) }\end{array}$ \\
\hline Autonomic nervous activity & $\begin{array}{l}\text { Ratio of heart rate variability: } \\
\text { Decreased in wooden environ- } \\
\text { ment }\end{array}$ & $\begin{array}{l}\text { Before and after stay in hospital } \\
\text { waiting room with pine walls } \\
\text { and ceilings, and larch furniture }\end{array}$ & $\begin{array}{l}\text { Adult subjects } \\
\mathrm{n}=40\end{array}$ & $\begin{array}{l}\text { Kotradyova et al. } \\
\text { (2019) }\end{array}$ \\
\hline Brain activity & $\begin{array}{l}\text { EEG }(\alpha) \text {, EEG }(\beta) \text {, and SMR } \\
\text { waves: } \\
\text { Initially decreased, and after a } \\
\text { while EEG }(\beta) \text { waves increased }\end{array}$ & & $\mathrm{n}=4$ & \\
\hline
\end{tabular}

The two studies investigating tactile sensations are mentioned under 'Stimulation' column

pressure was detected in participants in the 'standard' room, whereas it increased in the room with added wood. Additionally, the diastolic blood pressure tends to decrease in the 'standard' room, but no significant differences were reported between the two rooms in other measurements.

In the second study, Tsunetsugu et al. (2005) used the same test settings as in the first study with 15 male subjects. The same measures were used, but regional cerebral blood flow (rCBF) measurement was added. The results were similar to those from the first study: Pulse rate and diastolic blood pressure decreased in the 'standard' room, while pulse rate increased and diastolic blood pressure did not change in the other room. Furthermore, rCBF increased in both rooms, but no significant differences existed between the two rooms in terms of blood flow, mood, or subjective evaluation.

The third study by Tsunetsugu et al. (2007) investigated the physiological responses of 15 male subjects to three different surface wood ratios $(0 \%, 45 \%$ and $90 \%)$ of actual-size living rooms. The measures used otherwise were the same as in the second study, but changes in total hemoglobin concentration $(\mathrm{tHb})$ were measured as an index of central nervous activity instead of rCBF. In the subjective evaluation, the $45 \%$ room tended to be evaluated as the most comfortable and restful. The $90 \%$ and $45 \%$ rooms were evaluated as natural, while the $0 \%$ room was evaluated as the most artificial. Diastolic blood pressure decreased significantly in all three rooms. A significant decrease in systolic blood pressure was measured in the $90 \%$ room and pulse rate increased significantly in the $45 \%$ room, whereas these two indices did not change in the $0 \%$ room.

Sakuragawa et al. (2005) studied the influence of visual stimulation from full-size wooden Japanese cypress wall panels and white steel wall panels with 14 male subjects. The subjects were exposed to different panels for $90 \mathrm{~s}$ while their blood pressure and pulse rate were measured, and after the exposure, subjective evaluation and mood test were performed. The measured mood scale scores on depression/ dejection were significantly lower for the visual stimulation from the cypress wall panels than the control, and conversely, scores for visual stimulation by white wall panels were significantly higher. In physiological measurements, the researchers found that subjects who reported liking cypress panels had a significant decrease in systolic blood pressure during exposure to cypress wall panels. Subjects who reported liking steel wall panels maintained stable blood pressure when exposed to a steel wall, whereas the subjects who reported disliking the steel panel registered significant increase in blood pressure during the exposure.

Ohta et al. (2008) studied the effects of redecorating a hospital isolation room on the stress level of seven male subjects. Two actual isolation rooms in a hospital were used, with one room redecorated with wood panelling and Japanese rice paper, and the other used as a conventional hospital room with white painted concrete walls and ceiling boards. The subjects stayed in the rooms for $26 \mathrm{~h}$ and their physiological responses were monitored during and after staying in the rooms. The investigated parameters included heart rate, blood pressure, arterial vascular compliance, and plasma levels of cortisol, antidiuretic hormone, oxytocin, adrenaline, noradrenalin and dopamine. The plasma cortisol levels remained significantly lower after staying in the redecorated room compared with the control room, which according to the authors suggests that natural materials may provide a less-stressful environment. No significant differences between the two rooms were found with other studied parameters.

Fell (2010) investigated the stress responses of 119 subjects in four different office-like environments before, during, and after a stressful mental test. During the study, sympathetic nervous system activity was monitored by measuring the subjects' skin conductivity. Measures for cardiovascular responses to stress included inter-beat interval and heart rate variability. The test-room setups were: no plants and non-wooden furniture, plants with non-wooden furniture, no plants and wooden furniture, and plants with wooden furniture. The values of frequency of non-specific 
skin conductance responses were significantly lower during the pre-test and post-test periods in the rooms with wooden furniture, indicating that the subjects in the presence of wood were less-stressed than subjects in the rooms without wooden furniture. Similar effects for indoor plants were not found.

Zhang et al. (2017) studied physiological responses to wooden indoor environment using five test rooms simulating an office environment. The test-room setups were: non-wooden preparation room, non-wooden test room, and three wooden rooms with different contrasts. Twenty adult subjects completed work tasks during 60-min exposure periods to different rooms, while physiological parameters such as electrocardiogram measurements, skin temperature, skin resistance, blood pressure, oxyhemoglobin saturation $\left(\mathrm{SpO}_{2}\right)$, and near-distance vision were monitored. The researchers found out that the mean value of systolic blood pressure was significantly lower during the test and $\mathrm{SpO}_{2}$ values were slightly higher in the three wooden rooms compared with the non-wooden room. A similar trend was observed with the ratio of low frequency and high frequency heart rate variability, which was lower in wooden rooms than in the non-wooden room. Additionally, the mean value of near visual distance was slightly, but not significantly, higher in the wooden rooms in the beginning of the experiment, and it was significantly higher in one of the rooms at 52 min measurement compared to the non-wooden room. According to the authors, these results indicate that people felt less stress and tension in wooden environments. These results were supported by results from a simultaneous survey made by Zhang et al. (2016), where they studied different psychological responses to the same rooms by systematic and quantitative tests. They found out that in the wooden rooms the subjects had more positive emotions and fatigue evaluation values were dramatically lower compared to nonwooden room.

Burnard and Kutnar (2019) examined human stress responses to wood in two office-like environments with a total of four test settings. The test settings in both offices were a control environment with white furniture and no visible wood and a wooden environment with wood furniture. The wooden environment in one office was made with oak veneered furniture, and in the other with American walnut furniture. The study had a total of sixty-one subjects, both male and female aged between 18 and 52. During the 75-min test phase, stress was induced in subjects, so that they were able to observe and analyze stress responses and recovery. Salivary free cortisol was analyzed from seven saliva samples collected during the test phase and used as an indicator of stress responses. The cortisol concentration levels were significantly lower throughout the entire test period and during the response period (35-75 $\mathrm{min})$ in the oak environment compared to the control environment. No significant differences were detected between the walnut environment and the control environment.

Kotradyova et al. (2019) studied physiological responses to wood in a hospital waiting room. Experiments were executed on forty adult volunteers (both male and female) before entering, during, and after their stays in the waiting room. The waiting room was decorated with wooden wall panels and ceiling cladding made from solid pine wood, seating made of larch timber, and new warm white lighting. The subjects' heart rate, heart rate variability, and respiration activity were recorded, and their cortisol concentration was measured before and after the stay in the room. Additionally, brain activity of four subjects was analyzed from recorded electroencephalograph (EEG). They found out that ratio low frequency and high frequency heart rate variability decreased in the wooden environment, and modest increase in heart rate and respiration frequency was measured. Cortisol concentration had modest tendency towards decreasing but no significant differences were found. Brain wave recordings showed decreased brain activity in the wooden waiting room compared to the former space. Time progress during the time in the waiting room showed that EEG $(\alpha)$ and SMR waves decreased, and EEG $(\beta)$ waves increased, which according to the researchers indicate that the subjects' brains became more active after the initial relaxation.

All in all, in the reviewed studies some differences were found with the used physiological indices between wooden and non-wooden environments for both visual and tactile stimulation. In eight out of the eleven studies, the results indicated that wood materials may provide less stressful environments. In two studies, the results were somewhat opposite but there were only small differences (wooden beams and columns) between the investigated rooms (Tsunetsugu et al. 2002, 2005). However, the reviewed studies had several limitations and observations which hinder the possibilities to draw concrete conclusions about the stress relieving effects of interior wood. With the exception of research made by Ohta et al. (2008), Fell (2010), Zhang et al. (2017), Burnard and Kutnar (2019), and Kotradyova et al. (2019), the used exposure time was $90 \mathrm{~s}$ or less, which makes it difficult to confirm physiological stability (Zhang et al. 2017), and to translate such data to daily reallife situations and long-term effects. Further, the number of participants was 20 or less in most of the studies, comprising students in their 20s. However, positive physiological results were obtained as well in the studies with greater sample sizes and age variation. It was also noticed that different wood quantities (Tsunetsugu et al. 2007), contrasts of the used wood (Zhang et al. 2017; Burnard and Kutnar 2019), and personal preferences (Sakuragawa et al. 2005, 2008) affected the measured responses. Additionally, there exist preferences for different material combinations, and 
wood surfaces together with painted surfaces or other elements might add preferred complexity in the indoor environment (Nyrud et al. 2014; Burnard and Kutnar 2019), which may have been a significant factor in the majority of the reviewed studies. Therefore, it is difficult to separate whether these responses are directly from wood-derived stimulation and how to generalize the obtained results.

\section{Conclusion}

The findings from this literature review reveal:

\subsection{Chemical emissions}

Chemical emissions from wood depend on several factors such as tree species, part of tree (heartwood or sapwood), and growing location. Emissions from softwoods are dominated by terpenes and followed by aldehydes in lower concentrations, while carbonyl compounds and alcohols are the main emission products from hardwoods. Except for formaldehyde and acrolein, emitted chemicals are unlikely to cause sensory irritation because relevant indoor air concentrations are usually significantly below their thresholds for sensory irritation. Indoor air concentrations of some compounds, such as terpenes, aldehydes, and acids, can be close or above their odour thresholds, which may affect the perceived IAQ. Indoor terpenes have potential to react with oxidants and form fine particles and more irritating compounds. However, measured concentrations of key oxidation products are too low to cause sensory irritation or airflow limitation. In addition, exposure to some terpenes has been connected to positive health effects, for example, anti-inflammatory effects, and psychological and physiological relaxation.

\subsection{Moisture buffering}

Wood as a hygroscopic material has the ability to moderate the daily fluctuation of indoor relative humidity without increasing the amount of ventilation. Additionally, there is potential to reduce energy used for heating and cooling with latent heat of sorption, especially together with a wellcontrolled HVAC system. However, moisture buffering performance is affected by multiple factors, which complicates exploiting the moisture buffering effect of wood in real-life situations.

\subsection{Antibacterial effects}

Clear antibacterial activity has been detected on Scots pine and European oak, and European larch and Norway spruce have exhibited antibacterial characteristics. Mechanisms behind the antibacterial activity are not completely understood, but it has been noticed that hygroscopic drying of wood surfaces, wood extractives, and volatile organic compounds participate in it. Significant differences were found in the antibacterial effects between different tree species, parts of tree, wood extractives, and gaseous volatile organic compounds in combination with various bacterial strains. Therefore, the antibacterial effects are not easily explained or generalized, and the activity either derive from synergistic effects of multiple factors or varies between different tree species.

\subsection{Acoustical properties}

Wood is considered as a sound reflecting material with a relatively low sound absorption coefficient. Wood's sound absorption capability is based on its porous structure, but a small number of continuous pores reduce wood's permeability, resulting in a low sound absorption coefficient. The sound insulation performance of wood is poor compared with other frequently used building materials, such as concrete and brick. Therefore, wood's acoustic properties are most suitable for spaces that require sound reflection and enhanced sound performance, such as auditoriums and concert halls, but in combination with other materials and decent design it can be utilized in several different environments.

\subsection{Psychological and physiological effects}

Wood is generally perceived as a positive and natural material in both visual perception and tactile sensation, and it is commonly preferred when compared with other building materials and wood-based products. However, some studies suggest that intermediate levels of wood are preferred over extensive use or no wood at all. Differences have been found in physiological responses between exposure to wood and other materials, and the majority of the studies indicated that wood materials may provide less stressful environments. However, there are several limitations in these studies. The number of participants was small in most studies, comprising students in their 20s. However, positive psychological effects were discovered in studies that had greater sample sizes and more age variation among the subjects. Further, the experimental design in many studies was not complete, which causes difficulty to identify whether the measured responses are derived directly from exposure to wood or do they actually occur from exposure to more visual and complex environment. Furthermore, with one exception, the exposure times were between $60 \mathrm{~s}$ and $75 \mathrm{~min}$, and therefore, 
it is uncertain how the results can be reflected to real-life situations with long-term exposure.

Acknowledgements Open access funding provided by Aalto University. The authors warmly acknowledge Tekes-the Finnish Funding Agency for Innovation (Grant 4093/31/2015) for funding this research.

Author contributions TA took primary responsibility for planning the work, collecting the literature, and writing the original draft of the manuscript. RM, PP, and HS instructed and supervised the research process as well as reviewed and edited the final version of the manuscript.

\section{Compliance with ethical standards}

Conflict of interest The authors declare no conflicts of interests. The founding sponsor had no role in the design of the study; in the collection, analyses, or interpretation of data; in the writing of the manuscript, and in the decision to publish the results.

Open Access This article is licensed under a Creative Commons Attribution 4.0 International License, which permits use, sharing, adaptation, distribution and reproduction in any medium or format, as long as you give appropriate credit to the original author(s) and the source, provide a link to the Creative Commons licence, and indicate if changes were made. The images or other third party material in this article are included in the article's Creative Commons licence, unless indicated otherwise in a credit line to the material. If material is not included in the article's Creative Commons licence and your intended use is not permitted by statutory regulation or exceeds the permitted use, you will need to obtain permission directly from the copyright holder. To view a copy of this licence, visit http://creativecommons.org/licenses/by/4.0/.

\section{References}

Abadie M, Mendonca K (2009) Moisture performance of building materials: from material characterization to building simulation using the moisture buffer value concept. Build Environ 44:388-401

Ak N, Cliver D, Kaspar C (1994a) Decontamination of plastic and wooden cutting boards for kitchen use. J Food Prot 57(1):23-30

Ak N, Cliver D, Kaspar C (1994b) Cutting boards of plastic and wood contaminated experimentally with bacteria. J Food Prot 57(1):16-22

Al Horr Y, Arif M, Kaushik A, Mazroei A, Katafygiotou M, Elsarraq E (2016) Occupant productivity and office indoor environment quality: a review of literature. Build Environ 105:369-389

Asdrubali F, Ferracuti B, Lombordi L, Guattari C, Evangelisti L, Grazieschi G (2017) A review of structural, thermo-physical, acoustical, and environmental properties of wooden materials for building applications. Build Environ 114:307-322

Bengtsson P, Sanati M (2004) Evaluation of hydrocarbon emissions from heart- and sapwood of Scots pine using laboratory-scale wood drier. Holzforschung 58:660-665

Berger G, Katz H, Petutschnigg A (2006) What consumers feel and prefer: haptic perception of various wood flooring surfaces. For Prod J 56(10):42-47

Bhatta S, Tlippana K, Vahtikari K, Hughes M, Kyttä M (2017) Sensory and emotional perception of wooden surfaces through fingertip touch. Front Psychol 8:367
Bibi H, Reany O, Waisman D, Keinan E (2015) Prophylactic treatment of asthma by an ozone scavenger in a mouse model. Bioorg Med Chem Lett 25:342-346

Broman O (1995) Visual impressions of feature in Scots pine wood surfaces: a qualitative study. For Prod J 45(3):61-66

Broman O (2001) Aesthetic properties in knotty wood surfaces and their connection with people's preferences. J Wood Sci 47:192-198

Bucur V (1995) Acoustics of wood. CRC Press, Boca Raton

Burnard M, Kutnar A (2015) Wood and human stress in the built indoor environment: a review. Wood Sci Technol 49:969-986

Burnard M, Kutnar A (2019) Human stress responses in office-like environments with wood furniture. Build Res Inf. https://doi. org/10.1080/09613218.2019.1660609

Burnard M, Nyrud A, Bysheim K, Kutnar A, Vahtikari K, Hughes M (2017) Building material naturalness: perceptions from Finland, Norway and Slovenia. Indoor Built Environ 26(1):92-107

Cometto-Muniz J, Abraham M (2015) Compilation and analysis of types and concentrations of airborne chemicals measured in various indoor and outdoor human environments. Chemosphere 127:70-86

Dayawansa S, Umeno K, Takakura H, Hori E, Tabuchi E, Nagashima Y, Oosu H, Yada Y, Suzuki T, Ono T, Nishijo H (2003) Autonomic responses during inhalation of natural fragrance. Auton Neurosci Basic Clin 108:79-86

Dematte L, Zucco G, Roncato S, Gatto P, Paulon E, Cavalli R, Zanetti M (2018) New insights into the psychological dimension of wood-human interaction. Eur J Wood Prod 76:1093-1100

Eriksson K, Levin J, Sandström T, Lindström-Espeling K, Linden G, Stjernber N (1997) Terpene exposure and respiratory effects among workers in Swedish joinery shops. Scand J Work Environ Health 23(2):114-120

Fell D (2010) Wood in the human environment: restorative properties of wood in the built indoor environment [Dissertation]. University of British Columbia, Vancouver

Fick J, Pommer L, Nilsson C, Anderson B (2003) Effect of OH radicals, relative humidity, and time on the composition of the products formed in the ozonolysis of a-pinene. Atmos Environ 37:4087-4096

Filip S, Fink R, Oder M, Jevsnik M (2012) Hygienic acceptance of wood in food industry. Wood Sci Technol 46:657-665

Forssen J, Kropp W, Brunskog J, Ljunggren S, Bard D, Sandberg G, Ljunggren F, Agren A, Hallström O, Dybro H, Larsson K, Tillberg K, Jarnerö K, Sjökvist L, Östman B, Bolmsvik ^̊, Olsson A, Ekstrand C, Johansson M (2008) Acoustics in wooden buildings State of the art 2008-SP Report 2008:16. SP Technical Research Institute of Sweden, Stockholm

Gehrig M, Schnell G, Zurcher E, Kucera L (2000) Hygienic aspects of wood and polyethylen cutting boards regarding food contaminations. A comparison. Holz Roh Werkst 58:265-269

Geiss O, Giannopoulos G, Tirendi S, Barrero-Moreno J, Larsen B, Kotzias D (2011) The AIRMEX study-VOC measurements in public buildings and schools/kindergartens in eleven European cities: statistical analysis of the data. Atmos Environ 45:3676-3684

Gibson LT, Watt CM (2010) Acetic and formic acids emitted from wood samples and their effect on selected materials in museum environments. Corros Sci 52:173-178

Glasius M, Lahaniati M, Calogirou A, Ci Bella D, Jensen N, Hjorth J, Kotzias D, Larsen B (2000) Carboxylic acids in secondary aerosols from oxidation of cyclic monoterpenes by ozone. Environ Sci Technol 34:1001-1010

Gminski R, Tang T, Mersch-Sundermann V (2010) Cytotoxicity and genotoxicity in human lung epithelial A549 cells caused by airborne volatile organic compounds emitted from pine wood and oriented strand boards. Toxicol Lett 196:33-41 
Gminski R, Marutzky R, Kevekordes S, Fuhrmann F, Burger W, Hauschke D, Ebner W, Mersch-Sundermann V (2011) Sensory irritations and pulmonary effects in human volunteers following short-term exposure to pinewood emissions. J Wood Sci $57: 436-445$

Granström K (2005) Emissions of volatile organic compounds from wood [Dissertation]. Karlstad University, Karlstad

Granström K (2010) Underestimation of terpene exposure in the Nordic wood industry. J Occup Environ Hyg 7:144-151

Hameury S (2005) Moisture buffering capacity of heavy timber structures directly exposed to an indoor climate: a numerical study. Build Environ 40:1400-1412

Hameury S, Lundström T (2004) Contribution of indoor exposed massive wood to a good indoor climate: in situ measurement campaign. Energy Build 36:281-292

Hansen J, Nielsen G, Sorli J, Clause P, Wolkoff P, Larsen S (2013) Adjuvant and inflammatory effects in mice after subchronic inhalation of allergen and ozone-initiated limonene reaction products. J Toxicol Environ Health Part A 76(19):1085-1095

Hansen J, Norgaard A, Koponen I, Sorli J, Paidi M, Hansen S, Clausen P, Nielsen G, Wolkoff P, Larsen S (2016) Limonene and its ozone-initiated reaction products attenuate allergic lung inflammation in mice. J Immunotoxicol 13(6):793-803

Hedegaard L, Rode C, Peuhkuri R (2005) Full scale tests of moisture buffer capacity of wall materials. In: 7th Nordic symposium on building physics, Reykjavik, p 662

Hirota R, Nakamura H, Bhatti S, Ngatu N, Muzembo B, Dumavibhat N, Ettoku M, Sawamura M, Suganuma N (2012) Limonene inhalation reduces allergic airway inflammation in Dermatophagoides farinae-treated mice. Inhal Toxicol 24(6):373-381

Hoibo O, Nyrud A (2010) Consumer perception of wood surfaces: the relationship between stated preferences and visual homogeneity. J Wood Sci 56:276-283

Hyttinen M, Masalin-Weijo M, Kalliokoski P, Pasanen P (2010) Comparison of VOC emissions between air-dried and heat treated Norway spruce (Picea abies), Scotch pine (Pinus sylvesteris) and European aspen (Populus tremula) wood. Atmos Environ 44:5028-5033

Ikei H, Song C, Miyazaki Y (2016) Effects of olfactory stimulation by a-pinene on autonomic nervous activity. J Wood Sci 62:568-572

Ikei H, Song C, Miyazaki Y (2017) Physiological effects of wood on humans: a review. J Wood Sci 63:1-23

Jensen L, Larsen A, Molhave L, Hansen M, Knudsen B (2001) Health evaluation of volatile organic compound (VOC) emissions from wood and wood-based materials. Arch Environ Health 56(5):419-432

Jonsson O, Lindberg S, Roos A, Hugosson M, Lindström M (2008) Consumer perceptions and preferences on solid wood, woodbased panels, and composites: a repertory grid study. Wood Fiber Sci 40(4):663-678

Joung D, Song C, Ikei H, Okuda T, Igarashi M, Koizumi H, Park B, Yamaguchi T, Takagaki M, Miyazaki Y (2014) Physiological and psychological effects of olfactory stimulation with D-limonene. Adv Hortic Sci 28(2):90-94

Joye Y (2007) Architectural lessons from environmental psychology: the case of biophilic architecture. Rev Gen Psychol 11(4):305-328

Kang C, Kang W, Chung W, Matsumura J, Oda K (2008) Changes in anatomical features, air permeability and sound absorption capability of wood induced by delignification treatment. J Fac Agric Kyushu Univ 53(2):479-483

Kang C, Kim G, Park H, Lee N, Kang W, Matsumura J (2010) Changes in permeability and sound absorption capability of yellow poplar wood by steam explosion treatment. J Fac Agric Kyushu Univ 55(2):327-332
Kasanen J, Pasanen A, Pasanen P, Liesivuori J, Kosma V, Alarie Y (1999) Evaluation of sensory irritation of 3-carene and turpentine, and acceptable levels of monoterpenes in occupational and indoor environment. J Toxicol Environ Health 56(Part A):89-114

Kavian-Jahromi N, Schagerl L, Durschmied B, Enzinger S, Schnabl C, Schnabl T, Petutschnigg A (2015) Comparison of the antibacterial effects of sapwood and heartwood of the larch tree focusing on the use in hygiene sensitive areas. Eur J Wood Prod 73:841-844

Kirkeskov V, Witterseh T, Funch L, Kristiansen E, Molhave L, Hansen M, Knudsen B (2009) Health evaluation of volatile organic compound (VOC) emission from exotic wood products. Indoor Air 19(2):45-57

Kotradyova V, Vavrinsky E, Kalinakova B, Petro D, Jansakova K, Boles M, Svobodova H (2019) Wood and its impact on humans and environment quality in health care facilities. Int J Environ Res Public Health. https://doi.org/10.3390/ijerph16183496

Kraniotis D, Nore K, Bruckner C, Nyrud A (2016) Thermography measurements and latent heat documentation of Norwegian spruce (Picea abies) exposed to dynamic indoor climate. J Wood Sci 63:203-209

Krol S, Namiesnik J, Zabiegala B (2014) a-Pinene, 3-carene and D-limonene in indoor air of Polish apartments: the impact of air quality and human exposure. Sci Total Environ 468-469:985-995

Kurnitski J, Kalamees T, Palonen J, Eskola L, Seppänen O (2007) Potential effects of permeable and hygroscopic lightweight structures on thermal comfort and perceived IAQ in a cold climate. Indoor Air 17:37-49

Laireiter CM, Schanbel T, Köck A, Stalzer P, Petutschnigg A, Oostingh GJ, Hell M (2013) Active anti-microbial effects of larch and pine wood on four bacterial strains. BioResources 9(1):273-281

Li Q, Matsushima H, Miyazaki Y, Krensky A, Kawada T, Morimoto K (2006) Phytoncides (wood essential oils) induce human natural killer cell activity. Immunopharmacol Immunotoxicol 28:319-333

Li Q, Morimoto K, Nakadai A (2007) Forest bathing enhances human natural killer activity and expression of anti-cancer proteins. Int J Immunopathol Pharmacol 20(S):3-8

Li Q, Morimoto K, Kobayashi M (2008) Visiting a forest, but not a city, increases human natural killer activity and expression of anti-cancer proteins. Int J Immunopathol Pharmacol 21:117-127

Li Q, Kobayashi M, Wakayama Y, Inagaki H, Katsumata M, Hirata Y, Hirata K, Shimizy T, Kawada T, Park B, Ohira T, Kagawa T, Miyazaki Y (2009) Effect of phytoncide from trees on human natural killer cell function. Int J Immunopathol Pharmacol 22(4):951-959

Li Y, Fazio P, Rao J (2012) An investigation of moisture buffering performance of wood paneling at room level and its buffering effect on a test room. Build Environ 47:205-216

Lindberg S, Roos A, Kihlstedt A, Lindström M (2013) A product semantic study of the influence of the sense of touch on the evaluation of wood based materials. Mater Des 52:300-307

Mandin C, Trantallidi M, Cattaneo A, Canha N, Mihucz V, Szigeti T, Mabilia R, Perreca E, Spinazze A, Fossati S, Kluizenaar Y, Cornelissen E, Sakellaris I, Saraga D, Hänninne O, Fernandes E, Ventura G, Wolkoff P, Carrer P, Bartzis J (2017) Assessment of indoor air quality in office buildings across Europe- the OFFICAIR study. Sci Total Environ 579:169-178

Manninen AM, Pasanen P, Holopainen JK (2002) Comparing the VOC emissions between air dried and heat-treated Scots pine wood. Atmos Environ 36:1763-1768

Martins C, Santos P, Almeida P, Godinho L, Dias A (2015) Acoustic performance of timber and timber-concrete floors. Constr Build Mater 101:684-691 
Matsubara E, Kawai S (2014) VOCs emitted from Japanese cedar (Cryptomeria japonica) interior walls induce physiological relaxation. Build Environ 72:125-130

Milling A, Kehr R, Wulf A, Smalla K (2005a) The use of wood in practice-a hygienic risk? Holz Roh Werkst 63:463-472

Milling A, Kehr R, Wulf A, Smalla K (2005b) Survival of bacteria on wood and plastic particles: dependence on wood species and environmental conditions. Holzforschung 59:72-81

Morikawa T, Miyazaki Y, Kobayashi S (1998) Time-series variations of blood pressure due to contact with wood. J Wood Sci 44:495-497

Nazaroff W, Weschler C (2004) Cleaning products and air fresheners: exposure to primary and secondary air pollutants. Atmos Environ 38:2841-2865

Nore K, Nyrud A, Kraniotis D, Skulberg K, Englund F, Aurlien T (2017) Moisture buffering, energy potential, and volatile organic compound emissions of wood exposed to indoor environments. Sci Technol Build Environ 23(3):512-521

Nyrud A, Bringslimark T (2010) Is interior wood use psychologically beneficial? A review of psychological responses toward wood. Wood Fiber Sci 42(2):202-218

Nyrud A, Bringslimark T, Bysheim K (2014) Benefits from wood interior in a hospital room: a preference study. Archit Sci Rev 57(2):125-131

Ohta H, Maruyama M, Tanabe Y, Hara T, Nishino Y, Tsujino Y, Morita E, Kobayashi S, Shido O (2008) Effects of redecoration of a hospital isolation room with natural materials on stress levels of denizens in cold season. Int J Biometerol 52:331-340

Osanyintola O, Simonson C (2006) Moisture buffering capacity of hygroscopic building materials: experimental facilities and energy impact. Energy Build 38:1270-1282

Pohleven J, Burnar M, Kutnar A (2019) Volatile organic compounds emitted from untreated and thermally modified wood-a review. Wood Fiber Sci 51(4):1-24

Rautio M, Sipponen A, Peltola R, Lohi J, Jokinen J, Papp A, Carlson P, Sipponen P (2007) Antibacterial effects of home-made resin salve from Norway spruce (Picea abies). APMIS 115:335-340

Rice J, Kozak R, Meitner M, Cohen D (2006) Appearance wood products and psychological well-being. Wood Fiber Sci 38(4):644-659

Risholm-Sundman M, Lundgren M, Vestin E, Herder P (1998) Emissions of acetic acid and other volatile organic compounds from different species of solid wood. Holz Roh Werkst 56:125-129

Roffael E (2006) Volatile organic compounds and formaldehyde in nature, wood and wood based panels. Holz Roh Werkst 64:144-149

Rohr A (2013) The health significance of gas- and particle-phase terpene oxidation products: a review. Environ Int 60:145-162

Rohr A, Wilkins C, Clausen P, Hammer M, Nielsen G, Wolkoff P, Spengler J (2002) Upper airway and pulmonary effects of oxidation products of (+)-a-pinene, d-limonene, and isoprene in balb/c mice. Inhalation Toxicol 14:663-684

Sakuragawa S, Miyazaki Y, Kaneko T, Makital T (2005) Influence of wood wall panels on physiological and psychological response. J Wood Sci 51:136-140

Sakuragawa S, Kaneko T, Miyazaki Y (2008) Effects of contact with wood on blood pressure and subjective evaluation. J Wood Sci 54:107-113

Salazar J, Meil J (2009) Prospects for carbon-neutral housing: the influence of greater wood use on the carbon footprint of a singlefamily residence. J Clean Prod 17:1563-1571

Salonen H, Salthammer T, Morawska L (2018) Human exposure to ozone in school and office indoor environments. Environ Int 119:503-514

Salthammer T, Mentenese S, Marutzky R (2010) Formaldehyde in the indoor environment. Chem Rev 110:2536-2572
Schäfer M, Roffael E (2000) On the formaldehyde release of wood. Holz Roh Werkst 58:259-264

Schlink U, Rehwage M, Damm M, Richter M, Borte M, Herbarth O (2004) Seasonal cycle of indoor-VOCs: comparison of apartments and cities. Atmos Environ 38:1181-1190

Schönwalder A, Kehr R, Wulf A, Smalla K (2002) Wooden boards affecting the survival of bacteria? Holz Roh Werkst 60:249-257

Seaman VY, Bennett DH, Cahill TM (2007) Origin, occurrence, and source emission rate of acrolein in residential indoor air. Environ Sci Technol 41:6940-6946

Simonson C, Salonvaara M, Ojanen T (2002) The effects of structures on indoor humidity-possibility to improve comfort and perceived air quality. Indoor Air 12:243-251

Smardzewski J, Batko W, Kamisinski T, Flach A, Pilch A, Dziurka D, Mirski R, Roszyk E, Majewski A (2014) Experimental study of wood acoustic absorption characteristics. Holzforschung 68(4):467-476

Smardzewski J, Kamisinski T, Dziurka D, Mirski R, Majewski A, Flach A, Pilch A (2015) Sound absorption of wood-based materials. Holzforschung 69(4):431-439

Spetic W, Kozak R, Cohen D (2007) Perceptions of wood flooring by Canadian householders. For Prod J 57(6):34-38

Steckel V, Welling J, Ohlmeyer M (2011) Product emissions of volatile organic compounds from convection dried Norway spruce (Picea abies (L.) H. Karst.) timber. Int Wood Prod J 2(2):75-80

Sueyoshi S, Miyazaki Y, Morikawa T (2004a) Physiological and psychological responses to prolonged light floor impact sounds generated by a tapping machine in wooden house. J Wood Sci 50:494-497

Sueyoshi S, Miyazaki Y, Morikawa T (2004b) Physiological and psychological responses to a heavy floor-impact sound generated by dropping an automobile tire in a wooden house. J Wood Sci 50:490-493

Tamás G, Weschler C, Toftu J, Fanger P (2006) Influence of ozonelimonene reactions on perceived air quality. Indoor Air 16:168-178

Trantallidi M, Dimitroulopoulou C, Wolkoff P, Kephalopoulos S, Carrer P (2015) EPHECT III: health risk assessment of exposure to household consumer products. Sci Total Environ 536:903-913

Tsunetsugu Y, Miyazaki Y, Sato H (2002) The visual effects of wooden interiors in actual-size living rooms on the autonomic nervous activities. J Physiol Anthropol 21(6):297-300

Tsunestugu Y, Miyazaki Y, Sato H (2005) Visual effects of interior design in actual-size living rooms on physiological responses. Build Environ 40:1341-1346

Tsunetsugu Y, Miyazaki Y, Sato H (2007) Physiological effects in humans induced by visual stimulation of room interior with different wood quantities. J Wood Sci 53:11-16

Tsunetsugu Y, Park BJ, Miyazaki Y (2010) Trends in research related to "Shinrin-yoku" (taking in the forest atmosphere or forest bathing) in Japan. Environ Health Prev Med 15:27-37

Tyrväinen L, Ojala A, Korpela K, Lanki T, Tsunetsugu Y, Kagawa T (2014) The influence of urban green environments on stress relief measures: a field experiment. J Environ Psychol 38:1-9

Uhde E, Salthammer T (2007) Impact of reaction products from building materials and furnishing on indoor air quality-a review of recent advances in indoor chemistry. Atmos Environ 41:3111-3128

Vainio-Kaila T, Kyyhkynen A, Viitaniemi P, Siitonen A (2011) Pine heartwood and glass surfaces: easy method to test the fate of bacterial contamination. Eur J Wood Prod 69:391-395

Vainio-Kaila T, Rautkari L, Nordströ K, Närhi M, Natri O, Kairi M (2013) Effect of extractives and thermal modification on antibacterial properties of Scots pine and Norway spruce. Int Wood Prod J 4(4):248-252 
Vainio-Kaila T, Kyyhkynen A, Rautkari L, Siitonen A (2015) Antibacterial effects of extracts of Pinus sylvestris and Picea abies against Staphylococcus aureus, Enterococcus faecalis, Escherichia coli, and Streptococcus pneumoniae. BioResources 10(4):7763-7771

Vainio-Kaila T, Zhang X, Hänninen T, Kyyhkynen A, Johansson L, Willför S, Österberg M, Siitonen A, Rautkari L (2017a) Antibacterial effects of wood structural components and extractives from Pinus sylvestris and Picea abies on methicillin-resistant Staphylococcus aureus and Escherichia coli O157:H7. BioResources 12(4):7601-7614

Vainio-Kaila T, Hänninen T, Kyyhkynen A, Ohlmeyer M, Siitonen A, Rautkari L (2017b) Effect of volatile organic compounds from Pinus sylvestris and Picea abies on Staphylococcus aureus, Escherichia coli, Streptococcus pneumoniae and Salmonella enterica serovar Typhimurimum. Holzforschung 71(11):905-912

Välimaa A, Honkalampi-Hämäläinen U, Pietarinen S, Willför S, Holmbom B, von Wright A (2007) Antimicrobial and cytotoxic knotwood extracts and related pure compounds and their effects on food-associated microorganisms. Int J Food Microbiol 115:235-243

Vartiainen E, Kulmala M, Ruuskanen T, Taipale R, Rinne J, Vehkamäki $\mathrm{H}$ (2006) Formation and growth of indoor air aerosol particles as a result of D-limonene oxidation. Atmos Environ 40:7882-7892

Wang C, Barratt B, Carslaw N, Doutsi A, Dunmore R, Ward M, Lewis A (2017) Unexpectedly high concentrations of monoterpenes in a study of UK homes. Environ Sci Process Impacts 19:528-537

Watchman M, Potvin A, Demers C (2017) A post-occupancy evaluation of the influence of wood on environmental comfort. BioResources 12(4):8704-8724

Wells JR, Schoemaecker C, Waring MS, Ham JE, Nelissen I, Wolkoff $P$ (2017) Reactive indoor air chemistry and health—a workshop summary. Int J Hyg Environ Health 220:1222-1229

Weschler C (2004) Chemical reactions among indoor pollutants: what we've learned in the new millenium. Indoor Air 14(Suppl 7):184-194

Weschler C, Carslaw N (2018) Indoor chemistry. Environ Sci Technol 52:2419-2428
Weschler C, Shields H (1999) Indoor ozone/terpene reactions as a source of indoor particles. Atmos Environ 33:2301-2312

Widhalm B, Ters T, Srebotnik E, Rieder-Gradinger C (2016) Reduction of aldehydes and terpenes within pine wood by microbial activity. Holzforschung 70(9):895-900

Wilkins C, Wolkoff P, Clausen P, Hammer M, Nielsen G (2003) Upper airway irritation of terpene/ozone oxidation products (TOPS). Dependence on reaction time, relative humidity and initial ozone concentration. Toxicol Lett 143:109-114

Wolkoff P (2013) Indoor air pollutants in office environments: assessment of comfort, health, and performance. Int J Hyg Environ Health 216:371-394

Wolkoff P, Nielsen GD (2017) Effects by inhalation of abundant fragrances in indoor air - an overview. Environ Int 101:96-107

Wolkoff P, Clausen P, Wilkings C, Nielsen G (2000) Formation of strong airway irritants in terpene/ozone mixtures. Indoor Air 10:82-91

Wolkoff P, Larsen S, Hammer M, Kofoed-Sorensen V, Clausen P, Nielsen G (2013) Human reference values for acute airway effects of five common ozone-initiated terpene reaction products in indoor air. Toxicol Lett 216:56-64

Wyon D (2004) The effects of indoor air quality on performance and productivity. Indoor Air 14(suppl. 7):92-101

Yang X, Fazio P, Ge H, Rao J (2012) Evaluation of moisture buffering capacity of interior surface materials and furniture in a full-scale experimental investigation. Build Environ 47:188-196

Zhang X, Lian Z, Ding Q (2016) Investigation variance in human psychological responses to wooden indoor environments. Build Environ 109:58-67

Zhang X, Lian Z, Wu Y (2017) Human physiological responses to wooden indoor environment. Physiol Behav 174:27-34

Publisher's Note Springer Nature remains neutral with regard to jurisdictional claims in published maps and institutional affiliations. 